Cahiers $d u$ MONDE RUSSE

\section{Cahiers du monde russe}

Russie - Empire russe - Union soviétique et États indépendants

48/2-3 | 2007

Les résonances de 1905

\title{
«Označajuščee i označaemoe»
}

Igoŕ A.HRISTOFOROV

\section{OpenEdition \\ Journals}

Édition électronique

URL : https://journals.openedition.org/monderusse/8993

DOI : $10.4000 /$ monderusse. 8993

ISSN : $1777-5388$

Éditeur

Éditions de l'EHESS

Édition imprimée

Date de publication : 15 avril 2007

Pagination : 173-185

ISBN : 978-2-7132-2147-7

ISSN : $1252-6576$

\section{Référence électronique}

Igoŕ A.HRISTOFOROV, « «Označajuščee i označaemoe» », Cahiers du monde russe [En ligne], 48/2-3 | 2007, mis en ligne le 01 janvier 2007, consulté le 04 septembre 2022. URL : http://

journals.openedition.org/monderusse/8993; DOI : https://doi.org/10.4000/monderusse.8993 
chercher : repérer : avancer

Cet article est disponible en ligne à l'adresse :

http://www.cairn.info/article.php?ID REVUE=CMR\&ID NUMPUBLIE=CMR 482\&ID ARTICLE=CMR 4820173

\title{
«Označajuščee i označaemoe»
}

\author{
par Igớ A.HRISTOFOROV
}

\section{| Editions de l'EHESS | Cahiers du monde russe}

\section{7/2-3 - Vol 48}

ISSN 1252-6576 | ISBN 9782713221477 | pages 173 à 185

Pour citer cet article :

- A.HRISTOFOROV I., «Oznaajušee i oznaaemoe», Cahiers du monde russe 2007/2-3, Vol 48, p. 173-185.

Distribution électronique Cairn pour les Editions de l'EHESS.

(C) Editions de l'EHESS. Tous droits réservés pour tous pays.

La reproduction ou représentation de cet article, notamment par photocopie, n'est autorisée que dans les limites des conditions générales d'utilisation du site ou, le cas échéant, des conditions générales de la licence souscrite par votre établissement. Toute autre reproduction ou représentation, en tout ou partie, sous quelque forme et de quelque manière que ce soit, est interdite sauf accord préalable et écrit de l'éditeur, en dehors des cas prévus par la législation en vigueur en France. Il est précisé que son stockage dans une base de données est également interdit. 


\title{
«ОЗНАЧАЮЩЕЕ И ОЗНАЧАЕМОЕ»
}

\author{
Понятие «конституция» в российском политическом \\ дискурсе до и после 17 октября 1905 года ${ }^{1}$
}

В начале ноября 1905 г. Сергей Юльевич Витте, незадолго до того назначенный председателем Совета Министров, встречался с одним из лидеров кадетской партии Павлом Николаевичем Милюковым. Разговор вертелся вокруг провозглашенных Манифестом 17 октября перемен в государственном устройстве. Собеседники прощупывали друг друга, причем Милюков играл в «откровенность», а Витте по обыкновению был уклончив. «Если Ваши полномочия достаточны, отчего Вам не произнести этого решающего слова: конституция?»- настаивал Милюков. «Не могу, потому что царь этого не хочет», - «упавшим голосом» отвечал Витте. Беседа зашла в тупик.

Много лет спустя Милюков, вспоминая об этой встрече и отвергая упреки бывших товарищей по партии (прежде всего - Василия Алексеевича Маклакова) в упрямом нежелании поступиться «словом», когда «содержание его уже было уступлено», писал: «Бывают слова, которые звучат заклинанием и останавливают кровь; и бывают другие, такие же словасимволы, из-за которых кровь льется, ведутся внешние и гражданские войны, сокрушаются и возникают режимы. Когда появились у наших врагов слова-шибболеты, зачаровавшие массы, и слова все простые - мир, земля, право труда, классовая борьба, то нам нечего было им противопоставить. У нас отобрали наши слова: конституция, право, закон для всех равный. Не было “конституции”, пришла “революция”... Заговорить кровь было нечем... Вот почему я так настаивал, чтобы

1. Некоторые сюжеты, связанные с данной темой, затронуты в написанных автором разделах коллективной монографии «Первая революция в России: взгляд через столетие» (М.: Памятники исторической мысли, 2005, гл. 7-8). 
“слово” было произнесено; я его содержание сделал целью своей политической борьбы. Без него она теряла смысл, превращаясь в какую- то игру »².

В этой яркой и емкой цитате можно увидеть очень многое, касающееся и судьбы русского либерализма, и особенностей мировоззрения лидера кадетов. Я же хотел бы обратить внимание на то, что Милюков со свойственным ему чутьем очень точно уловил важнейшую особенность тогдашней политической борьбы вокруг изменения государственного строя империи: доминирующей в ней была дискурсивная составляющая. Иначе говоря, это была прежде всего игра слов и игра вокруг слов.

Удивительно, но именно этот аспект истории того, что принято называть российской конституцией и конституционализмом, редко привлекает внимание исследователей. Стала ли Россия конституционным государством, и если да, то в каком смысле или в какой мере, - так можно сформулировать вопрос, отвечая на который, политики тех лет порой приходили к неожиданным и парадоксальным выводам (не менее остро обсуждалась и иная проекция того же вопроса - о причинах и последствиях трансформации политического строя). Историки очень часто ограничиваются тем, что присоединяются к хору отвечающих на него. За сто истекших лет количество вариантов ответа, в общем-то, не изменилось.

Еще Маклаков, в эмиграции обвинявший руководство кадетской партии в недальновидности, поскольку требования истинного либерализма оно систематически приносило в жертву тактике и революционной демагогии, настаивал, что если считать конституцию противоположностью абсолютизму, то «Основные законы 1906 г. несомненно были конституцией. Их смысл не менялся от того, что их можно было иногда нарушать». Милюков же, по его мнению, «систематически и умышленно смешивал “конституцию” с “парламентаризмом”, хотя знал, что существуют “непарламентарные” конституции» ${ }^{3}$. Маклаков имел в виду государственное устройство, часто именуемое «дуалистической монархией», при котором народное представительство и монарх с подчиненным ему правительством составляют два центра власти, находящихся в подвижном и неустойчивом равновесии. Важнейшей же чертой парламентарного строя, как известно, считается установление ответственности правительства перед народным представительством. Отсутствие этой ответственности, как и ограниченность прав Думы в собственно законодательной сфере, и заставляли многих кадетов говорить о «лжеконституционном» характере российского государственного строя.

2. П.Н. Милюков, Воспоминания, т.1, М.: Современник, 1990, с. 330-332.

3. В.А. Маклаков, Первая Государственная Дума: Воспоминания современника: 27 апреля - 8 июля 1906 года, М.: Центрполиграф, 2006, с. 22, 26-28. 
Подобно Маклакову, многие российские и западные историки признают, что в России существовала конституция, хотя она была очень консервативной и часто нарушалась ${ }^{4}$. Это считается важным симптомом того, что Россия развивалась по пути, заданному западной цивилизацией, хотя политическая модернизация страны и осложнялась множеством разного рода факторов. Напротив, некоторые исследователи настаивают на том, что перемены в государственном устройстве создавали лишь «конституционный фасад», прикрывавший прежний по существу режим 5 . Существует и промежуточная точка зрения, согласно которой принципиальной чертой преобразований 1905-1906 гг. была их расплывчатость, неопределенность, позволявшие «каждой политической группе видеть в них нечто свое» ${ }^{6}$. Соответственно, новое политическое устройство страны могло эволюционировать в различных направлениях ${ }^{7}$.

Нередко подобные оценки явно или неявно подразумевают, что стержень политической борьбы составляло (за пределами революционного лагеря) противостояние различных «моделей» политической системы. Эти модели размещаются на некой абстрактной «шкале», на одном полюсе которой видится незыблемость дореволюционных порядков, на другом - тотальный их слом, а между двумя этими крайними вариантами - все многообразие умеренных и радикальных, заимствованных и «почвенных» вариантов конституционализма, вокруг которых группируются различные политические силы. Однако такое «моделирование» перестает работать, как только анализ проектов и деклараций дополняется анализом тактических маневров политиков и неопределенности использовавшихся ими ключевых понятий.

Термин «конституция» и родственные ему на протяжении всего XIX века играли в российском политическом лексиконе сложную провокативную и

4. В.В. Леонтович, История либерализма в России, М.: Русский путьПолиграфресурсы, 1995, с. 439-468; W.M. Butler, «Civil Rights in Russia: Legal Standards in Gestation», in Civil Rights in Imperial Russia, Oxford: Clarendon Press, 1989, p. 4-5; A. Asher, The Revolution of 1905. Vol. 2. Authority Restored. Stanford, 1992, p. 9495; Б.Н. Миронов, Социальная история России периода империи : ХVIII-начало ХХ в., Спб.: Дмитрий Буланин, 1999, т. 2, с. 154-160.

5. Г.Б. Васильева, Г.Б. Гальперин, А.И. Королев, Первая российская революция и самодержавие, Л.: Наука, 1975, с. 106-111, 129; Н.П. Ерошкин, История государственных учреждений дореволюционной России, М.: Высшая школа, 1983, c. 264; Sh. Fitzpatrick, The Russian Revolution, Oxford: Oxford University Press, 1990, p. 34-35, 38; А.Н. Медушевский, «Конституционная монархия в России», Bопросы истории, 1994, № 8, с. 45; его же. Демократия и авторитаризм: Российский конституционализм в сравнительной перспективе, М.: Росспэн, 1998, с. 198-201.

6. G. Hosking, The Russian Constitutional Experiment: Government and Duma, 1907-1914, Cambridge: Cambridge University Press, 1983, p. 243-244.

7. T. Emmons, The Formation of the Political Parties and the First National Elections in Russia. Cambridge, Mass.: Harvard University Press, 1983, p. 377-378. 
смыслопорождающую роль ${ }^{8}$. За пределами круга правоведов конституция, как правило, понималась не как основной закон, определяющий политическое устройство государства, регламентирующий взаимоотношения различных ветвей власти (и тем ограничивающий полномочия каждой из них), а как любая форма центрального представительства общественных интересов ${ }^{9}$. Такое представительство воспринималось не как источник суверенитета, а лишь как способ налаживания диалога власти и общества и/или как средство устранить «бюрократическое средостение» между монархом и народом. Это понимание конституции, характерное для так называемого «правительственного», как и для умеренного «земского» конституционализма, доминировало на протяжении всей второй половины XIX века. Подразумевалось, что представительство должно поэтому не ограничивать власть, a, напротив, усилить ее, дав ей понимание необходимого курса и опору в обществе ${ }^{10}$. Вместе с тем, оно должно было структурировать само это общество, признававшееся крайне аморфным (или, в крайнем варианте, - даже «создать» его в форме «политического класса» $)^{11}$.

Идея о государственной власти как главной созидающей силе, своеобразном демиурге российской истории и действительности имела очень глубокие идеологические корни. Как известно, именно она лежала, в частности, в основе комплекса исторических и правовых концепций, традиционно объединяемых рамками так называемой «государственной школы». Позитивистское направление этой школы, наиболее авторитетными представителями которого стали в пореформенное время Максим Максимович Ковалевский, Александр Дмитриевич Градовский и Николай Михайлович Коркунов, сыграло очень значительную роль в формировании в России либеральной идеологии ${ }^{12}$.

8. Несмотря на большое количество работ о «российском конституционализме» как общественно-политическом течении или как идее, история понятия «конституция» в России до сих пор не написана. В числе исследований «конституционализма» можно выделить: В.Г. Чернуха, Внутренняя политика иаризма с середины 50-х до начала 80-х г2. ХІХ в. Л.: Наука, 1978; С.С. Секиринский, В.В. Шелохаев. Либерализм в России: Очерки истории (середина 19 - начало 20 вв.). М.: Памятники исторической мысли, 1995; А.Н. Медушевский, Демократия и авторитаризм; А.Н. Верещагин. Земский вопрос в России: Политико-правовые аспекты. М.: Международные отношения, 2002. См. также: Е.Н. Рощин. «История понятия «суверенитет» в России», в: Исторические понятия и политические идеи в России: XVI-XX века. Спб.: Изд-во Европейского университета в С.-Петербурге; Алетейя, 2006, с. 190-230.

9. Ср.: В.Г. Чернуха, указ. соч., с. 21.

10. См. об этом: А.В. Мамонов, «Граф М.Т. Лорис-Меликов: к характерис тике взглядов и государственной деятельнос ти», Отечественная история. 2002. № 5.

11. См., например: [Фадеев Р.А.], Письма о современном состоянии России. Спб.: б.и., 1882.

12. См.: A. Walicki, Legal Philosophies of Russian Liberalism. Notre Dame: Notre Dame University Press, 1992; Верещагин, Указ. соч. 
Существенно иным было новое, «освобожденческое» понимание конституции как необходимого условия и результата реализации принципа народного суверенитета. Принципиально противопоставляя интересы наличной власти и «народа», «освобожденцы» (среди которых выделялись Милюков и Петр Бернгардович Струве), примыкавшие к ним радикальные земцы и общественные деятели видели в «правильной» (принятой Учредительным собранием, избранным по «четыреххвостке» ${ }^{13}$ ) конституции sine qua non установления нового «правового» порядка ${ }^{14}$. Наконец, достаточно широким был спектр неославянофильских подходов к народному представительству (сам термин «конституция» традиционалистами отвергался, по крайней мере, до 17 октября 1905 года, когда многие из них получили возможность стать, по тогдашней шутке, «конституционалистами по высочайшему повелению»). Отличительной особенностью неославянофильского взгляда на представительство можно считать отрицание его формально-правовых рамок, поскольку оно интерпретировалось как полумистическое средство «единения» самодержца с народом и преодоления бюрократического «средостения» ${ }^{15}$.

Выделяя три подхода к пониманию конституции, я не имею в виду, что они конкурировали друг с другом на равных в политических дебатах, формулировались и отстаивались четко очерченными политическими группами и были взаимоисключающими, альтернативными. Скорее можно считать их подобием осей, задававших систему дискурсивных координат, в которой и разворачивалось проектирование «конституционного строя». При этом многие важные его особенности восприятия определялись иными переменными величинами. Одной из них можно считать представление о «механизме рождения» этого строя.

Устойчивый образ появления конституции в результате единовременного акта сосуществовал в публичном дискурсе с интерпретацией ее как итога длительного процесса «вызревания». Такая амбивалентность создавала удобное поле для разного рода игр. Если конституцию можно создать (принять, даровать) одним росчерком пера, то сам этот акт приобретает принципиальное, роковое, почти магическое значение. Еще в сентябре 1865 года озабоченный резкими проявлениями дворянского конституционализма Александр II счел необходимым встретиться с одним из его активистов Дмитрием Дмитриевичем Голохвастовым. «...Вы <дворяне - И.Х. >,

13. Так именовались на либеральном жаргоне всеобщие, равные, прямые и тайные выборы.

14. См.: К.Ф. Шацилло, Конституционное движение накануне первой русской революции. М.: Наука, 1988.

15. Типичными для либерального варианта неославянофильства можно считать взгляды Д.Н. Шипова, а для консервативного - С.Ф. Шарапова. См.: Д.Н. Шипов, Воспоминания и думы о пережитом. М., 1918; С.Ф. Шарапов. Самодержавие и самоуправление. Берлин, 1899. 
конечно, уверены, что я из мелкого тщеславия не хочу поступиться своими правами! - заявил самодержец. - Я даю тебе слово, что сейчас, на этом столе, я готов подписать какую угодно конституцию, если бы я был убежден, что это полезно для России. Но я знаю, что сделай я это сегодня, и завтра Россия распадется на куски» ${ }^{16}$. Страна признавалась не готовой к «чуду», процесс «созревания» и акт «творения» парадоксально сополагались, заводя ситуацию в неразрешимый логический тупик. Примерно таким же был смысл расхожего мифа о подписании Александром II «конституции» за несколько часов до собственной гибели.

Как в свое время прекрасно показали применительно к реформам XVIII века Ю.М. Лотман и Б.А. Успенский, «волшебное», демиургическое творение «нового», столь свойственное идеологии российского реформаторства, разворачивалось преимущественно в языковой плоскости ${ }^{17}$. Создание есть именование, неверное именование или выбор неправильного момента для произнесения имени делает творение ущербным. В этом контексте милюковское сравнение слова «конституция» с «заклинанием» не выглядит удивительным. Но, настаивая на произнесении с высоты престола именно этого слова, лидер кадетов действительно отказывался, как и утверждал Маклаков, признать значение уже данного «царского слова» - Манифеста 17 октября.

Между тем и в верхах, и в общественной среде не было недостатка в людях, считавших, что именно Манифест создал «новую реальность». По выражению С.Ю. Витте, он «отрезает вчера от сегодня, прошедшее от будущего», так что «нет более старой России, а существует новая Россия». Одному из создателей Манифеста вторили ставший в кабинете Витте министром просвещения гр. Иван Иванович Толстой, считавший, что он означает «превращение России одним росчерком пера в правовое государство» и морской министр Алексей Алексеевич Бирилев, убежденный, что теперь «хорошая, новая жизнь потечет широкой струей» ${ }^{18}$. Участники первого общего собрания петербургских членов «Союза 17 октября» отправили в начале декабря на высочайшее имя телеграмму, не без развязности провозглашавшую «ура конституционному царю свободного народа» ${ }^{19}$. Даже некоторые кадеты оказались не свободны от эйфорического переживания момента «творения». Один из старейших по возрасту членов

16. Цит. по: Л.М. Ляшенко, Александр II. М.: Молодая гвардия, 2002, с. 115.

17. См.: Ю.М. Лотман, Б.А. Успенский, «Отзвуки концепции “Москва - Третий Рим” в идеологии Петра Первого (K проблеме средневековой традиции в культуре барокко)»; их же. «Споры о языке в начале ХІХ века как факт русской культуры» в Лотман Ю.М. История и типология культуры, СПб.: Искусство-СПБ, 2002.

18. Цит. по: Г.М. Кропоткин «Правящая бюрократия и “новый строй” российской государственности после манифеста 17 октября 1905 года», Отечественная история. 2006, №1, с. 28. Здесь же приводится еще целый ряд подобных суждений.

19. Партия «Союз 17 октября»: Протоколь съездов и заседаний ЦК. Т.1. 1905-1907. М.: Росспэн, 1996, с. 15. 
партии - Митрофан Павлович Щепкин, вспомнив о своих переживаниях в день обнародования Манифеста 19 февраля 1861 года, отменившего крепостное право, говорил на Первом ее съезде: «...Тогда освобождалось одно сословие, теперь свободен весь народ. И я ощутил ее теперь и увидел е - свободу, и мог бы сказать, как Симеон: "ныне отпущаеши раба Твоего, Владыко, с миром..." $»^{20}$ (Как не вспомнить тут описанную Ю.М. Лотманом мифологему «мгновенного, чудесного и полного преображения России» указами Петра, благодаря которым, по словам Антиоха Кантемира, «стали мы вдруг народ уже новый» ${ }^{21}$.)

В не менее драматические, исполненные почти религиозного пафоса тона (хотя и прямо противоположного оттенка) было окрашено восприятие Манифеста самим императором: «Да, России даруется конституция. Немного нас было, которые боролись против нее. Но поддержки в этой борьбе ниоткуда не пришло, всякий раз от нас отворачивалось все большее количество людей, и в конце концов случилось неизбежное» ${ }^{22}$. «Прости, Святая Русь...», - «невольно приходило на ум» совсем не склонному к мистике товарищу министра внутренних дел Сергею Ефимовичу Крыжановскому ${ }^{23}$.

При этом не было недостатка и в попытках рационалистического истолкования смысла Манифеста. Как писал Николай II матери, «предоставление гражданских прав населению - свободы слова, печати, собраний и союзов и неприкосновенности личности; кроме того, обязательство проводить всякий законопроект через Государственную Думу - это, в сущности, и есть конституция» ${ }^{24}$. В этом перечне, очевидно, только последний пункт мог вызвать столь острые переживания монарха (в том же письме он называл подписание манифеста «страшным решением»). Однако, по верному наблюдению Б.В. Ананьича и Р.Ш. Ганелина, «во всех царских высказываниях, основанных на том, что решающее значение имел именно акт 17 октября, как бы не принималось во внимание, что совещание Сольского ${ }^{25}$ шаг за шагом, но неуклонно вело дело к принятию тех же преобразований» ${ }^{26}$. Разница между законодательным и законосовещательным представительством была, с точки зрения практики, трудноуловима,

20. Съезды и конференции конституционно-демократической партии. Т.1 : 1905 1907. М.: Росспэн, 1997, с. 34.

21. Ю.М. Лотман, «Роль дуальных моделей в динамике русской культуры (до конца хVIII века)» в Лотман, История и типология культуры, с. 106.

22. Цит. по: Б.В. Ананьич, Р.Ш. Ганелин, Сергей Юльевич Витте и его время. СПб.: Дмитрий Буланин, 2000, с. 224.

23. С.Е. Крыжановский, Воспоминания, Берлин: [Б.и., б.г.], с. 56.

24. Красный архив, т. 22, 1927, с. 168.

25. Это совещание разрабатывало проекты реформ государственного строя, обещанных в феврале в манифесте о создании «булыгинской» Думы.

26. Ананьич, Ганелин, Сергей Юльевич Витте и его время, с. 225. 
краткость же и неясность Манифеста 17 Октября оставляли открытым вопрос о его реализации в конкретных правовых нормах. Таким образом, рационалистическая трактовка совершившегося «перелома» явно отступала на второй план перед символической.

Представление о длительном «вызревании конституции» оставалось в сознании современников не менее устойчивым. При этом начальная точка этого процесса могла размещаться в далеком или недавнем прошлом, в настоящем и даже в будущем (в последнем случае, в соответствии с распространенным штампом, признавалось, что страна/народ/общество «еще не созрели» для представительного строя). Так или иначе, этот подход предполагал, что, используя слова Крыжановского, «русская конституция или, вернее, обновленный строй нарождались из внутреннего развития государства » ${ }^{27}$. При этом подразумевалось, что государство далеко опережало в прочности другие общественные элементы: «если чем Россия и держалась, то, несомненно, работой чиновничества» ${ }^{28}$ В результате, утверждал Крыжановский, «хотя “конституция” и оказалась, но тут лишь заметили, и раскрыла это Первая Дума, что не оказалось “граждан”, способных к ее восприятию... Подавляющая масса населения, крестьянство, жила еще в общинных привычках и мировоззрениях, решительно не вязавшихся с правовым строем. Приходилось начинать постройку гражданственности с создания “граждан”» ${ }^{29}$ (то есть с аграрной реформы).

Инверсия либерального образа «конституции» как «увенчания здания» очень точно отражала восприятие представителя правящей элиты, почувствовавшего «вдруг» разверзшуюся под ногами пустоту. Учитывая, что сама Дума, по Крыжановскому, была лишь «органом перевоспитания общества», да и «административный фундамент империи» так и остался «в архаическом состоянии» ${ }^{30}$, круг замыкался: у творящего действительность государства не оказывалось никакой опоры, конституция же представала случайной, хрупкой и эфемерной конструкцией в окружавшем ее море хаоса, в котором видимость оформленности поддерживалась лишь катастрофическим напряжением сил правительства. Разительность этого образа становится еще более очевидной, если вспомнить, что именно Крыжановский и был одним из непосредственных «творцов» конституции, ответственным в правительстве за разработку правовых аспектов нового государственного устройства. Не случайно для Милюкова он был никем иным как «магом и волшебником конституционного права»!

27. С.Е. Крыжановский, «Заметки русского консерватора», Вопросы истории, 1997 , № 2, c. 125 .

28. Там же, № 3 , с. 134

29. Там же, с. 126

30. Крыжановский, Воспоминания, с. 115, 140-141. 
В свою очередь, либералы представляли конституцию жизненно важным условием «созревания» страны. В этом Милюков и «умеренные» типа Маклакова или Сергея Павловича Шипова оказывались почти единодушными. Однако «заклинанию словом», по логике Милюкова, подлежал не только «народ», но и правящая элита, магический заряд «слова» должен был преобразить и того, кто его произносит - самодержца, превратив его в конституционного монарха. При этом в условиях, поскольку предполагалось, что и страна, и власть к «настоящей конституции» едва ли готовы, формы и органичность представительства большого значения не имели. Вопрос о государственном устройстве полностью переносился в область тактики: речь шла лишь о подготовке «стартовой площадки», поля для политической борьбы. В уже цитировавшейся беседе с Витте Милюков прямо заявил, что предоставить выработку конституции самой Думе «слишком рискованно», и предложил: «Позовите кого-нибудь сегодня и велите перевести на русский язык бельгийскую или, еще лучше, болгарскую конституцию, завтра поднесите ее царю, а послезавтра опубликуйте» ${ }^{31}$. Мог ли он не понимать, что подобным образом жизнеспособное политическое устройство не создается?

Неудивительно, что в дальнейшем кадеты, давая ту или иную оценку установленному в 1906 г. строю, действительно руководствовались потребностями момента. Когда нужно было подчеркнуть прерогативы Думы и тот факт, что монарх уже не всевластен, всячески акцентировалась идея соблюдения конституции; когда же речь заходила о необходимости «ограничить произвол», поддерживалась точка зрения, что «настоящую» конституцию еще только предстоит создать. В этой терминологической игре, открывавшей перед партией множество возможностей для тактического маневра, Маклаков и видел основную ошибку е руководителей. Но подобными играми занималась и власть!

Витте, прекрасно знакомый со “славянофильской” идеологической парадигмой и на заре своей правительственной карьеры, еще при Александре III, не раз с успехом к ней прибегавший, к концу 1905 года уже неплохо ориентировался и в либеральной системе ценностей. Его попытки то выпятить, то затушевать в зависимости от ситуации смысл Манифеста 17 октября сводились именно к спекуляциям на расплывчатости понятия «конституция». «Меня тогда же поразило, - вспоминал о встрече с ним еще весной 1905 г. профессор Александр Андреевич Брандт, - что С.Ю. Витте говорил как-то одновременно и о даровании конституции, и о сохранении

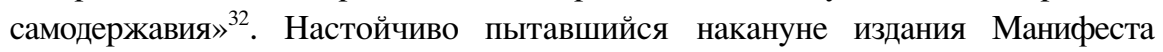
«приучить» царя «не бояться» рокового «слова», после 17 октября он все чаще разворачивался в прямо противоположную сторону.

31. Милюков, Воспоминания, т.1, с. 330-331.

32. Цит. по: Ананьич, Ганелин, Сергей Юльевич Витте и его время, с. 186. 
Правда, в начале января 1906 года он еще заявлял своему противнику, министру финансов Владимиру Николаевичу Коковцову, что «вообще не видит никакого просвета и смотрит на вещи самым безнадежным образом, не чувствуя доверия к себе Государя и не видя его готовности идти дальше по пути реформ и введения у нас настоящей, а не “детской”... конституции, с уступкой народному представительству большей части своих прав» ${ }^{33}$. Однако уже на царскосельских совещаниях, где в присутствии царя обсуждались изменения в Основных законах, он не раз довольно неуклюже прибегал к идеям из традиционалистского арсенала. Так, обсуждая полномочия реформируемого Государственного Совета, Витте настаивал, что «рассматриваемое преобразование еще не составляет конституции», а на следующий день даже счел нужным выразить опасение, как бы Совет не стал «средостением» между царем и крестьянами: «Они и смотрят на Думу так найдем через нее доступ к царю, найдем расправу... Скажут, думали, что будет доступ, а между тем чиновники отдалили нас от государя». Когда же Коковцов сказал, что предлагаемый премьером путь «знаменует переход к одной палате», он услышал от Витте: «Я смотрю так, что Владимир Николаевич желает конституционный порядок управления, а я считаю, что этого нельзя». Тут не выдержал престарелый гр. Константин Иванович Пален, еще при Александре II бывший министром юстиции: «Что такое конституция? Граф Витте сказал, что в Манифесте 17 октября никакой конституции не содержится. Не подлежит, однако, сомнению, что Россия будет управляться по конституционному образцу...». «Ни один факультет университета не определяет конституции, как граф Пален, - парировал Витте. Прежде всего, у нас нет присяги на верность устанавливаемому строю. Государь император вводит этот строй по собственной инициативе. Какая же это конституция?... Напрасно относиться с пренебрежением к психологии общества, а особенно крестьян, где психология всё - Царь и Бог!» Виттевскую трактовку конституции тут же опровергли члены совещания, юристы Федор Густавович Тернер и Николай Степанович Таганцев, а в перерыве Пален, предупредив императора об опасности предложения Витте, добавил: «А говорить, что Вы не дали конституции, значит куртизанить» ${ }^{34}$.

Аналогичным образом, хотя, возможно, с большей искренностью, пытался нащупать смысловые границы пресловутого «слова» и связанных с ним понятий и сам Николай II. При обсуждении на том же совещании новой редакции статьи об императорской власти, он, рассказав о своих колебаниях

33. В.Н. Коковцов, Из моего прошлого: Воспоминания 1903-1919 г2., кн. 1, М.: Современник, 1992, с. 93.

34. Российское самодержавие в начале хх века: от абсолютной $\kappa$ думской монархии: Сборник документов и материалов о реформах государственного строя России в 1905-1907 г2., М.: [Б.и.], 1998, с. 152, 160-161; «Из дневника А.А. Половцова», Красный архив, 1923, № 4, с. 90-91. 
и поддержке, получаемой от «всякого сословия людей», выразил кредо, способное поставить в тупик любого, кто попытался бы оценить его с точки зрения формальной логики: «Акт 17 октября дан мною вполне сознательно, и я твердо решил довести его до конца. Но я не убежден в необходимости при этом отречься от самодержавных прав... Могут сказать, что это отступление от обещаний, данных 17 октября. Я это знаю и понимаю... Но надо уразуметь, с чьей стороны будет укор. Он, конечно, последует со стороны всего так называемого образованного элемента, пролетариев, третьего сословия. Но я уверен, что $80 \%$ русского народа будет со мною...» ${ }^{35}$

О том, что очевидная противоречивость этого выступления не была случайной, говорит его предыстория. Еще 1 декабря 1905 г. во время приема депутации «Союза землевладельцев» на прямой вопрос «сохранил ли император свое самодержавие после 17 октября» царь не нашелся, что ответить, и был им смущен ${ }^{36}$. Зато уже 16 февраля правой депутации из Иваново-Вознесенска он, по версии Александры Викторовны Богданович, заявил: «Передайте вашим братьям и единомышленникам, что я, как встарь, буду самодержавный и неограниченный. Милости, дарованные манифестами, я исполню для блага всего моего народа» ${ }^{37}$. Вероятно, позицию Николая II можно объяснить тем, что он воспринял точку зрения, неоднократно подсказывавшуюся ему правыми. Суть ее заключалась в следующем: Манифестом 17 октября государь установил новый порядок управления, признав его полезным, но в его же власти вновь изменить его, если выяснится, что он негоден. Вопрос о конституционном характере перемен, как и драматическое восприятие их как необратимого «шага в неизвестность» подменялись оценкой их как почти рутинного волеизъявления самодержца. И если попытки столь резкого дискурсивного поворота в условиях революции не могли не быть довольно робкими, то после «замирения» страны такая интерпретация как будто оказывается само собой разумеющейся.

В сентябре 1909 года Петр Аркадьевич Столыпин в известном интервью журналисту Николаю Гарвею ${ }^{38}$ растолковывал поучающим тоном: «Сколько времени... было потрачено, да и до сих пор тратится на бесплодные споры о том, самодержавие у нас или конституция? Как будто дело в словах, как будто трудно понять, что Манифестом 17 октября с высоты престола предуказано развитие чисто русского, отвечающего и народному духу и историческим преданиям государственного устройства? Государю угодно

35. Российское самодержавие в начале хх века..., с. 205-206.

36. «25 лет назад : Из дневника Л.Тихомирова», Красный архив, 1930, № 4/5, с. 113.

37. А.В. Богданович, Три последних самодержиа, М.: АПН, 1990, с. 371.

38. Именно его премьер заключил знаменитыми словами: «Дайте государству 20 лет покоя, внутреннего и внешнего, и вы не узнаете нынешней России!» 
было призвать народных представителей себе в сотрудники. Можно ли после того говорить, что народное представительство “урвало” от царской власти?» ${ }^{39}$ Трудно представить себе более некорректную трактовку Манифеста. Однако возможные упреки в искажении истины премьера явно не беспокоили. Контроль над положением в стране был, как казалось, восстановлен, а вместе с ним - и контроль над «производством смыслов».

Таким образом, ни одна политическая сила ни в ходе революции, ни после нее не была заинтересована в том, чтобы слово «конституция» стало кровеостанавливающим препаратом. Не подкрепленное магией слова, здание представительной монархии было обречено оседать и рассыпаться.

\section{Институт российской истории Российской академии наук}

ikhrist@yandex.ru

39. Интервью опубликовано в: П.Н. Зырянов, Петр Стольпин : Политический портрет. М.: Просвещение, 1992, с. 128-133, (цит. на с. 129). 